\title{
PROJEKTOVANJE AUTOMATSKIH SKLADIŠTA U FARMACEUTSKOJ INDUSTRIJI
}

\section{DESIGN OF AUTOMADED STORAGE AND RETRIEVAL SYSTEMS IN PHARMACEUTICAL INDUSTRY}

\author{
Nenad KOSANIĆ, \\ Mašinski fakultet Univerziteta u Beogradu, Beograd \\ nkosanic@mas.bg.ac.rs
}

U radu su predstavljene neke osnovne smernice za projektovanje automatskih skladišta $u$ farmaceutskoj industriji: vrste skladištenog materijala, uslovi čuvanja materijala, osnovne karakteristike podsistema za prijem materijala, osnovne karakteristike podsistema za komisioniranje i zahtevani ambijentalni uslovi. Predstavljen je analitički model za određivanje očekivanih vremena ciklusa dizalice kod automatskih skladišta opsluživanih dizalicama sa regalima dvostruke dubine, budući da je ovo, verovatno, najčešće korišćena tehnologija skladištenja u podsistemu glavnog skladišta u farmaceutskim fabrikama. Usled izuzetne važnosti ispunjenja savremenih zahteva za distribucijom malih, frekventnih porudžbina, predstavljeni su analitički modeli za određivanje očekivanih vremena ciklusa kod automatskih skladišta za male terete opsluživanih dizalicama $i$ automatskih skladišta za male terete opsluživanih skladišnim vozilima, koja definišu protok transportnih jedinica kroz sistem. Svi navedeni modeli mogu poslužiti projektantima i inženjerima koji se ovim problemima bave u praksi, kao $i$ proizvođačima ovih sistema, da odrede meru uspešnosti projektnih rešenja, odnosno, da garantuju potencijalnim korisnicima najvažnije performanse sistema.

Ključne reči: automatska skladišta; farmaceutska industrija; analitički modeli; performanse sistema

The paper addresses some basic guidelines for the automated storage and retrieval systems design in pharmaceutical industry: types of pharmaceutical materials, materials storage keeping conditions, receiving subsystem main characteristics, order picking subsystem main characteristics and requested environment conditions. Analytical travel time model for the estimation of cycle times for the unit-load double-deep automated storage and retrieval systems is presented as it is the most common automated storage and retrieval systems type in main warehouse subsystem in pharmaceutical industry. Due to the great importance of very frequent small orders distribution in today's logistic, analytical travel time model for the computation of travel cycle times for mini-load multi-shuttle automated storage and retrieval system and shuttle based storage and retrieval systems are presented. All models could help designers, professionals in practice even a producers of these systems to estimate successions of offered solutions or to guarantee most important system performance achievement.

Key words: Automated storage and retrieval systems; Pharmaceutical industry; Analytical models; System performances

\section{Uvod}

Osnovne prednosti korišćenja automatskih skladišnih sistema $(A S / R S)$ su visok protok skladišnih jedinica kroz sistem, efikasno iskorišćenje prostora, visoka pouzdanost, bolja kontrola zaliha, poboljšani uslovi bezbednosti skladištenja robe, smanjenje oštećenja i nedostatka određenih artikala. U većini slučajeva ovi sistemi ispunjavaju uslove „zelene“ logistike i ergonomije u radu. Trend automatizacije će nastaviti da bude "zlatni" standard u procesima rukovanja materijalom i skladišnim procesima i u bliskoj budućnosti. Sa druge strane, $(A S / R S)$ su skupi sistemi, nefleksibilni za buduće promene, pa je za njihov uspešan rad neophodno pažljivo projektovanje. Postoje više tipova $(A S / R S)$, T. Lerher [1]:

- automatska skladišta opsluživana dizalicama koja transportuju palete (unit-load $A S / R S$ ),

- automatska skladišta opsluživana dizalicama koja transportuju male terete - kontejnere (miniload $A S / R S$ ),

- automatska skladišta opsluživana autonomnim vozilima koja transportuju palete (AVS/RS), 
- automatska skladišta opsluživana skladišnim vozilima (,šatl-ovima“) koja transportuju male terete - kontejnere $(S B S / R S)$,

Sistemi se mogu podeliti na sisteme u kojima dizalice rade u jednom hodniku i sisteme u kojima dizalice opslužuju više hodnika. Regali u sistemima mogu biti jednostruke, dvostruke ili višestruke dubine. Dizalice su izvedene sa podiznim uređajem koji istovremeno mogu transportovati jednu, dve ili tri transportne jedinice (TJ).

Počeci automatizacije datiraju iz ' 60 . godina prošlog veka. Prvo automatsko skladište visine 20 m za palete izgrađeno je u Nemačkoj 1962. godine. U ' 90 . godinama nastala je nova evolucija uvođenjem (mini-load $A S / R S$ ), u kojima su TJ u obliku kontejnera, kartonskih pakovanja ili različitih plastičnih sudova. Prednost (mini-load $A S / R S$ ) je u nižim investicionim ulaganjima u odnosu na protok TJ kroz sistem. Slabost sistema ogleda se u visokoj potrošnji energije skladišnih dizalica i u ograničenoj mogućnosti proširenja sistema. Usled povećanih zahteva za visokim protokom TJ kroz sistem, kao i smanjenjem vremena ispunjenja skladišnih zahteva, konstruisane su skladišne dizalice koje mogu istovremeno da nose do 3 TJ.

Najnovija tehnologija u automatskim skladištima zasniva se na tzv. autonomnim skladišnim vozilima - ,šatl-ovima““ $(S B S / R S)$. Ova relativno nova tehnologija može ostvariti protok do 1000 TJ na čas, i ima mogućnost povećanja broja vozila u svakom trenutku. Sistem je najčešće energetski efikasniji u poređenju sa (mini-load $A S / R S$ ). Međutim, sistem može zahtevati visoke investicije i veoma složeni sistem upravljanja vozilima. $(S B S / R S)$ je konkurentan (mini-load $A S / R S)$ samo kada se zahteva visok protok TJ kroz sistem, čija masa ne prelazi $50 \mathrm{~kg}$ po skladišnom vozilu.

U farmaceutskoj industriji, u samim fabrikama, podsistem glavnog skladišta najčešće se izvodi u obliku $(A S / R S)$ sa regalima jednostruke ili dvostruke dubine, usled boljeg iskorišćenja prostora. Podsistem za komisioniranje izvodi se kao (mini-load $A S / R S$ ) ili kao $(S B S / R S)$, a prikupljanje porudžbina se obavlja po principu „roba čoveku“.

U prošlosti prikupljanje porudžbina je obično bilo definisano međusobnim uticajima (odnosom) skladišta i veletrgovina. U novije vreme, opšti trend smanjenja troškova u logistici primorao je distributere farmaceutskih proizvoda da snabdevaju i mnoge klijente koji zahtevaju frekventnije, ali u isto vreme izuzetno male porudžbine. Tu spadaju i tzv. „on-line“ kupovine, kupovine putem „pametnih" telefona i drugi oblici elektronskog naručivanja farmaceutskih proizvoda. Sa ovakvim, za distributere veoma nezgodnim tržišnim zahtevima, proizvođači automatskih sistema za manipulaciju materijala, odgovorili su razvojem i usavršavanjem $(S B S / R S)$ sistema.

U poslednjih 50 godina (unit-load $A S / R S$ ) su bila predmet mnogih istraživanja. W.H. Hausman i ost. [2] su analizirali jednostruke cikluse (SCC) automatskih dizalica za regale „kvadratne u vremenu“ (SIT) poredeći performanse sistema za tri predložene strategije rada. Graves i ost. [3] su proširili prethodni model na rad dizalice sa dvostukim ciklusima (DCC). A. Y. Bozer i A. J. White [4] su razvili analitičke modele za određivanje vremena $S C C$ i $D C C$ dizalice za regale opšteg oblika (koji nisu SIT). Njihovi analitički modeli se baziraju na strategiji slučajnog određivanja skladišne lokacije sa različitim konfiguracijama ulaznih i izlaznih redova čekanja. Usvojen je redosled ispunjavanja zahteva za uskladištenjem i iskladištenjem, po redosledu njihovog pristizanja (FIFO disciplina u redu čekanja). M. H. Han i F. L. McGinnis [5] su pokazali da se protok TJ kroz sistem može povećati primenom heurističkog pravila najbližeg suseda $(N N)$, umesto FIFO redosleda ispunjavanja zahteva u skladištu. Prema autorima, vreme saobraćanja između lokacije uskladištenja i lokacije iskladištenja u $D C C$ se može smanjiti i do 50\%, što dovodi do povećanja protoka TJ od 10-15\%. Povećanje protoka može pomoći da se savladaju vršna opterećenja do kojih povremeno dolazi u radu sistema, ili da se čak otkloni potreba za jednim skladišnim hodnikom sa dizalicom, što dovodi do značajnih ušteda.

Svi navedeni autori su pretpostavljali da skladišna dizalica saobraća sa konstantnom brzinom, što nije u skladu sa realnim sistemom.

T. Gudehus [6] je predložio analitičke izraze za određivanje vremena saobraćanja dizalice, koji se zasnivaju na ubrzanju, konstantnoj brzini saobraćanja i usporenju pri kretanju. Razmatrani su SCC i $D C C$ za SIT regale. Analitičke modele za određivanje vremena saobraćanja dizalice uzimajući u obzir, ubrzanje, konstantnu brzinu i usporenje za regale opšteg oblika, takođe, su predstavljeni kod autora $\mathrm{H}$. Hwang i S. B. Lee [7], S. Vössner [8] i M. Vidovića [9].

Većina naučnika analizirala je $(A S / R S)$ kod kojih se dizalice nalaze u svakom hodniku i transportuju samo jednu transportnu jedinicu. Proučavanjem $(A S / R S)$ u kome dizalica opslužuje više skladišnih hodnika predstavili su H. Hwang i S. C. Ko [10]. Oni su predložili izraz za vreme kretanja 
dizalice, pretpostavljajući da se dizalica premešta u susedne hodnike pomoću automatskog uređaja za prebacivanje, a proučavali su i problem podele hodnika u klase u cilju minimizacije broja dizalica. Njihov rad bazira se na modelima kretanja dizalice samo sa konstantnom brzinom, što nije u skladu sa stvarnim načinom rada sistema.

T. Lerher i ost. [11, 12] su predstavili analitičke modele za određivanje vremena kretanja dizalice u $(A S / R S)$ u kojima dizalica opslužuje više hodnika, uzimajući u obzir stvarne radne karakteristike dizalice. Modeli su razvijeni za slučajno dodeljivanje lokacija uskladištenja i iskladištenja, i pri pretpostavci da se ovi zahtevi mogu javiti u istom ili susednim hodnicima.

Proučavanjem $(A S / R S)$ sistema u kojima dizalica istovremeno nosi više TJ bavili su se A. Keserla i A. B. Peters [13]. Oni su predstavili heurističku strategiju za minimiziranje vremena kretanja između lokacije uskladištenja i iskladištenja u $D C C$, kao i poboljšanja protoka kroz sistem ostvarenog korišćenjem četvorostrukih ciklusa $(Q C C)$ u poređenju sa $D C C$. Analitički modeli za $(A S / R S)$ kod kojih dizalica istovremeno nosi više TJ predstavljeni su i u radu R. D. Meller i A. Mungwatana [14]. Pri radu sistema sa $Q C C$ i šestostrukim ciklusima $(S T C)$ dizalice, predstavljena su heuristička pravila $N N$ i obrnutog najbližeg suseda $(R N N)$ za modifikaciju $Q C C$ i $S T C$. Njihovi analitički modeli zasnivaju se na pretpostavci da se dizalica kreće konstantnom brzinom (osnova za njihov rad bili su analitički modeli koje su razvili A. Y. Bozer i A. J. White [4]. T. Lerher i ost. [15]) predstavili su analizu (mini-load $A S / R S$ ) kod koga dizalice nose više TJ.

Analize $(A S / R S)$ sa regalima dvostruke dubine predstavljeni su u radovima J. Oser i P. Garlock [16], J. Oser i M. Ritonja [17] i M. Ritonja [18]. U Z. Sari i ost. [19] proučavani su $(A S / R S)$ sa regalima višestruke dubine. U ovim istraživanjima predstavljen je model kretanja dizalice za protočne regale dubine do 3 TJ. M. B. De Koster i ost. [20] su predstavili regal optimalnih dimenzija za kompaktno skladište dubine do 3 TJ. Predstavljena je kombinacija dizalica i sistema ulaznih i izlaznih (pogonskih i nepogonskih transportera) za kretanje po dubini regala. U nastavku rada, Y. Yu i M. B. De Koster [21] su izveli očekivano vreme $S C C$ pod pretpostavkom potpunog obrta svih skladišnih jedinica. U cilju uvođenja strategije TJ različitih klasa, Y. Yu i M. B. De Koster [22] predstavili su model za određivanje optimalnih granica zona u kompaktnom skladištu sa regalima trostruke dubine.

T. Lerher i ost. [23] su se bavili regalima dvostruke dubine. Predstavljeni modeli razmatraju realne radne karakteristike dizalice i uslove prebacivanja TJ koja blokira pristup željenoj TJ, na mesto prve slobodne skladišne lokacije za vreme procesa iskladištenja. Predloženi modeli omogućavaju izračunavanje srednjeg vremena $S C C$ i $D C C$.

$\mathrm{X}$. Xu i ost. [24] su proučavali regale dvostruke dubine u $(A S / R S)$ sa dizalicom koja nosi dve TJ. Ovakvi sistemi imaju bolje iskorišćenje skladišnog prostora od sistema sa regalima jednostruke dubine i dizalicama koje nose samo jednu TJ. Predstavljeni su analitički modeli koji tretiraju QCC, pri određivanju performansi sistema. Prikazana su značajna poboljšanja pri korišćenju dizalica koje transportuju dve TJ u odnosu na sisteme sa dizalicama koje nose samo jednu TJ.

Detaljan pregled istraživanja u oblasti $(A S / R S)$ dat je u J. Gu i ost. [25], a iscrpna objašnjenja trenutnog razvoja u oblasti $(A S / R S)$ data su u radu K. J. Roodbergen i F. A. Vis [26].

U literaturi nema mnogo referenci koje tretiraju $(S B S / R S)$ sisteme. H. J. Carlo i I. F. A. Vis [27] su proučavali $(S B S / R S)$ sa dva sistema liftova, usredsredivši se na problem određivanja redosleda korišćenja ovih liftova. Razvijeno je heurističko pravilo u cilju poboljšanja intenziteta protoka TJ kroz sistem. G. Marchet i ost. [28] modelirali su $(S B S / R S)$ sa otvorenim sistemima redova čekanja u cilju određivanja performansi sistema - iskorišćenja liftova i skladišnih vozila, vremena čekanja i broja TJ u redu čekanja ispred liftova. Rezultati analitičkih modela poređeni su sa rezultatima dobijenim simulacijom.

G. Marchet et al. [29] predstavili su osnovne kompromise pri projektovanju (SBS/RS), korišćenjem simulacionog pristupa. Istraživanje je izvedeno na nekoliko projektnih konfiguracija za sisteme u kojima vozila rade na samo jednom nivou regala. Predstavljeno je nekoliko performansi sistema: iskorišćenje liftova i skladišnih vozila, prosečno vreme protoka TJ kroz sistem, vremena čekanja, kao i troškovi konfiguracije skladišnog regala. T. Lerher i ost. [30] predstavili su analitički model za izračunavanje vremena ciklusa u $(S B S / R S)$. Predloženi model razmatra stvarne radne karakteristike lifta i skladišnog vozila, uzimajući u obzir ubrzanje, usporenje i maksimalnu brzinu kretanja. Model omogućuje izračunavanje srednjeg vremena $S C C$ i $D C C$ iz kojih se može dobiti protok TJ kroz sistem. U kasnijem radu, T. Lerher et al. [31] su predstavili performanse $(S B S / R S)$ sistema dobijene simulacijom. Cilj istraživanja bio je da se ispitaju prednosti projektnog rešenja 
sistema, koje smanjuju srednja vremena ciklusa transportnih zahteva. Poređenje performansi sistema obavljeno je za nekoliko konfiguracija skladišnih regala, profila brzina i ubrzanja skladišnih vozila i podiznog stola liftova. T. Lerher [32] je proučavao $(S B S / R S)$ sa regalima dvostruke dubine, predstavivši analitičke modele za izračunavanje vremena ciklusa skladišnog vozila i podiznog stola lifta. Modeli razmatraju realne radne karakteristike vozila i liftova, kao i uslove prebacivanja plastičnog kontejnera koji blokira pristup željenoj lokaciji, na mesto prve slobodne skladišne lokacije, pri procesu iskladištenja. Očekivana vremena $S C C$ i $D C C$ koriste se za izračunavanje protoka kroz sistem sa regalima dvostruke dubine.

Poslednjih godina, T. Lerher i ost. [33], T. Lerher [34], su razmatrali koncepte energetske efikasnosti u projektovanju $(A S / R S)$ i $(S B S / R S)$. Predloženim modelima poređene su performanse nekoliko projektnih rešenja sa različitim profilima brzina, ubrzanja i konfiguracija skladišnih regala. Performanse sistema su potrošnja energije, količina emitovanog $\mathrm{CO}_{2}$ i protok TJ kroz sistem. U T. Lerher [1] predstavljeni su pored pomenutih modela za izračunavanje srednjeg vremena ciklusa, količina potrošene energije i količina regenerisane energije za različita projektna rešenja sistema (različite konfiguracije regala i različite profile brzina i ubrzanja skladišnih vozila i liftova).

\section{Osnovne smernice u projektovanju $(A S / R S)$ u farmaceutskoj industriji}

1. Tokom izrade projekta potrebno je razdvojiti tokove kretanja materijala, odnosno, obezbediti po mogućstvu jednosmeran tok materijala, kao i odgovarajuće mere zaštite materijala u cilju sprečavanja eventualne pojave mešanja, zagađenja i unakrsnog zagađenja.

2. Prema vrsti skladištenog materijala, mogu se, npr., definisati sledeće grupe: sirovine, pakovni materijal, proizvodi u rasutom stanju koji se eksterno proizvode i donose u skladište, proizvodi u primarnom pakovanju u rasutom stanju koji se eksterno proizvode i dopremaju u skladište, gotovi proizvodi u rasutom stanju koji će se skladištiti do trenutka pakovanja, gotovi proizvodi, antibiotici i citostatici.

Materijali koji se skladište mogu se prema uslovima čuvanja svrstati u sledeće grupe: termosenzitivni materijali (režimi čuvanja $2-8^{\circ} \mathrm{C}$ i $15-25^{\circ} \mathrm{C}$ ); hidrosenzitivni materijali (režim čuvanja do $65 \%$ maksimalne relativne vlažnosti vazduha); materijali koji se čuvaju pod posebnim bezbednosnim uslovima; materijali koji nemaju posebnih zahteva za uslovima čuvanja, itd.

Materijali koji zahtevaju posebne bezbedonosne uslove čuvanja su: psihoaktivni materijali (aktivni principi i gotov proizvod), citostatici (gotov proizvod), štampani pakovni materijal, neusaglašeni materijali i gotovi proizvodi, opozvani/vraćeni proizvodi, lekovi sa oštećenom zaštitnom oznakom, lekovi sa oštećenim pakovanjem, lekovi za koje postoji sumnja o mogućoj zagađenosti, roba sa isteklim rokom trajanja i falsifikovani lekovi. Za skladištenje sirovina i pakovnog materijala u malim količinama koristi se, najčešće, automatski sistem u vidu vertikalnih liftova (sa nezavisnim sistemom kontrole pristupa). U posebnu grupu materijala koji se moraju čuvati pod posebnim bezbednosnim uslovima sa kontrolom pristupa, spada materijal koji podleže carinskom nadzoru (sirovine i gotovi proizvodi). Materijali koji spadaju u kategoriju opasnog materijala, takođe, se čuvaju u izdvojenom prostoru sa kontrolom pristupa.

3. U podsistemu za prijem materijala istovar se obavlja preko pretovarnih mesta sa kosim hidrauličnim pregibnim platformama i izolacionim zavesama „na naduvavanje“, radi smanjenja gubitka energije i bolje izolacije prostora oko vozila kao i radi istovara robe koja podleže tzv. „hladnom lancu“.

4. Uzorkovanje materijala se obavlja u podsistemu za prijem robe, a povezano je sa podsistemom glavnog skladišta. Služi za uzorkovanje sirovina i primarnog pakovnog materijala. Prostor u kome se obavlja uzorkovanje izvodi se u kategoriji „,̌istih soba“, sa najčešće, klasom čistoće vazduha ISO8 prema standardu ISO 14644:1.

5. Iz higijenskih razloga pojedine vrste materijala u farmaceutskoj industriji potrebno je čuvati na plastičnim ili metalnim paletama. Zbog toga se u podsistemu za prijem obavlja i prepaletiranje robe sa drvenih na higijenske palete. Koriste se dve vrste uređaja za prepaletiranje, automatski, uklopljen u transportni sistem za ulaz robe u podsistem glavnog skladišta (,,in-line“) i poluautomatski sa ručnim dopremanjem i otpremanjem paleta. 
6. Podsistem za komisioniranje izvodi se na nekoliko načina: klasična paletna skladišta sa „protočnim policama“ (komisioniranje po principu „čovek robi“); (mini-load $A S / R S$ ) sa komisioniranjem po principu ,roba čoveku“; $(S B S / R S)$ sa komisioniranjem po principu ,roba čoveku“.

7. U okviru podistema glavnog skladišta potrebno je predvideti prostor za materijal koji zahteva posebne bezbednosne uslove čuvanja.

8. Skladište se deli u zone prema zahtevanim parametrima ambijentalnih uslova.

Sve komponente sistema za obezbeđenje ambijentalnih uslova trebaju biti odabrane u skladu sa smernicama i zahtevima EU cGMP, EN ISO 14644 i ISPE vodiča za farmaceutsku industriju. Najveća količina materijala čuva se u podsistemu glavnog skladišta sa temperaturnim režimom $15-25^{\circ} \mathrm{C}$, i propisanom ralativnom vlažnošću vazduha. Za temperaturni režim $2-8^{\circ} \mathrm{C}$ predviđaju se rashladne komore. U podsistemima za prijem, otpremu, komisioniranje, kao i prostorijama u kojima se obavlja uzorkovanje sirovina i primarnog pakovnog materijala, najčešće se ostvaruje temperatura od $18-25^{\circ} \mathrm{C}$. U prostorijama uzorkovanja sirovina i primarnog pakovnog materijala, a koje se snabdevaju vazduhom kontrolisane čistoće, potrebno je ostvariti i zahtevane parametre čestičnog i mikrobiološkog opterećenja. Čestično i mikrobiološko opterećenje prostorija definisano je klasom vazduha kojim se prostor snabdeva, primer dat u tabeli 1.

Tabela 1 - Primer čestičnog i mikrobiološkog opterećenja prostorija

\begin{tabular}{|l|l|l|}
\hline $\begin{array}{l}\text { Klasa vazduha } \\
\text { (ISO/GMP) }\end{array}$ & $\begin{array}{l}\text { Čestično opterećenje ,at rest“ (prema ISO 14644-1 i } \\
\text { EU cGMP, Annex 1,2008) }\end{array}$ & $\begin{array}{l}\text { Mikrobiološko opterećenje } \\
\text { (prema EU cGMP, Annex 1, 2008) }\end{array}$ \\
\hline & $\begin{array}{l}\geq 0.5 \mu \mathrm{m}, \leq 3,520,000 \text { čestica } / \mathrm{m}^{3} \text { vazduha } \\
\text { ISO 8/ „D“ }\end{array}$ & $\begin{array}{l}\text { Aktivno uzorkovanje: } 200 \mathrm{cfu} / \mathrm{m}^{3} \text { vazduha } \\
\text { Pasivno uzorkovanje (Petri šoljom dijametra } \\
95.0 \mu \mathrm{m}, \leq 29,000 \text { čestica } / \mathrm{m}^{3} \text { vazduha }\end{array}$ \\
\hline
\end{tabular}

U tabeli 2 dat je primer zahtevane vrednosti nadpritisaka u prostorijama uzorkovanja, kao i smerova strujanja vazduha koje je potrebno obezbediti radi održavanja zahtevanih ambijentalnih uslova.

Tabela 2 - Primer zahtevanih vrednosti nadpritisaka

\begin{tabular}{|l|l|l|l|l|l|}
\hline $\begin{array}{l}\text { Broj prostorije/ } \\
\text { prostora }\end{array}$ & Naziv prostorije/prostora & $\begin{array}{l}\text { Klasa vazduha ISO } \\
14644\end{array}$ & $\begin{array}{l}\text { Temperatura } \\
\left({ }^{\circ} \mathrm{C}\right)\end{array}$ & $\begin{array}{l}\text { Pritisak u } \\
\text { prostoriji (Pa) }\end{array}$ & $\begin{array}{l}\text { Smer strujanja } \\
\text { vazduha }\end{array}$ \\
\hline P0.17 & Airlock (za personal) & ISO 8 & $18-25^{\circ} \mathrm{C}$ & $15( \pm 4)$ & $\mathrm{S} 0.12 \rightarrow \mathrm{S} 0.07$ \\
\hline P.019 & Uzorkovanje & ISO 8 & $18-25^{\circ} \mathrm{C}$ & $30( \pm 4)$ & $\begin{array}{l}\mathrm{S} 0.14 \rightarrow \mathrm{S} 0.12 \\
\mathrm{~S} 0.14 \rightarrow \mathrm{S} 0.13\end{array}$ \\
\hline-- & Airlock (za materijal) & ISO 8 & $18-25^{\circ} \mathrm{C}$ & $15( \pm 4)$ & $\mathrm{S} 0.13 \rightarrow \mathrm{S} 0.07$ \\
\hline
\end{tabular}

U zavisnosti od klase vazduha u komorama za pripremu vazduha upotrebljavaju se različite vrste filtera. HEPA filteri su poslednji u nizu filtera u sistemu za pripremu vazduha čistih soba.

U tabeli 3 dati su preporučeni nivoi filtracije vazduha u skladištu.

Tabela 3 - Preporučeni nivoi filtracije vazduha u skladištu

\begin{tabular}{|l|l|}
\hline Nivo zaštite & Preporučena filtracija \\
\hline Jednostepena filtracija & Samo primarni filteri - EN779 G4 filteri \\
\hline Trostepena filtracija & $\begin{array}{l}\text { Tamo gde postoji potencijal za unakrsno-zagađenje proizvoda. } \\
\text { Primarni, sekundarni i tercijarni filteri - EN779 G4, F7 i EN1822 H11 filteri. }\end{array}$ \\
\hline
\end{tabular}

Klasifikacija filtera u Tabeli 3 odnosi se na EN1822 i EN779 standarde testiranja filtera, koji su preporučeni za međunarodnu upotrebu (EN 779 se odnosi na filtere klase G1 do F9, a EN 1822 se odnosi na filtere klase H10 do U16).

$\mathrm{U}$ daljem tekstu predstavljeni su analitički modeli koji se koriste za primenjene tipove $(A S / R S) \mathrm{u}$ podsistemu glavnog skladišta i u podsistemu za komisioniranje, na osnovu kojih se dobijaju najvažnije performanse ovih sistema.

\section{Automatska skladišta opsluživana dizalicama koja transportuju palete (unit-load $A S / R S$ ) sa regalima dvostruke dubine}

U razvoju analitičkih modela usvojene su sledeće pretpostavke, T. Lerher i ost. [23]:

- sa obe strane skladišnog hodnika nalaze se regali dvostruke dubine,

- regali dvostruke dubine razmatrani su kao kontinualne pravougaone površine, a ulazno/izlazna lokacija (I/O) smeštena je u donjem levom uglu regala, 
- dizalica saobraća u jednostrukim ili dvostrukim ciklusima, i nosi istovremeno samo jednu paletu (TJ). TJ se odlaže najpre u dublju regalnu poziciju (drugi paletni niz TJ),

- dizalica je opremljena zahvatnim uređajem koji može zahvatiti TJ iz oba paletna niza,

- brzina i ubrzanje dizalice u oba pravca, kao i dužina i visina regala su poznati,

- dizalica se istovremeno kreće duž oba pravca,

- dužina i visina regala su dovoljni da se ostvare maksimalne brzine, započinjući kretanje iz I/O,

- usvojeno je pravilo slučajnog dodeljivanja lokacije uskladištenja i iskladištenja.

U modelu se koriste sledeće oznake:

$v_{x} \quad$ Maksimalna brzina dizalice $\mathrm{u}$ horizontalnom pravcu

$v_{y} \quad$ Maksimalna brzina dizalice u vertikalnom pravcu

$a_{x+} \quad$ Ubrzanje dizalice $\mathrm{u}$ horizontalnom pravcu

$a_{y+} \quad$ Ubrzanje dizalice u vertikalnom pravcu

$a_{x-} \quad$ Usporenje podiznog stola dizalice u horizontalnom pravcu

$a_{y-} \quad$ Usporenje podiznog stola dizalice u vertikalnom pravcu

$L \quad$ Dužina regala

$H \quad$ Visina regala

$n_{x} \quad$ Broj lokacija regala u horizontalnom praveu

$n_{y} \quad$ Broj lokacija regala u vertikalnom pravcu

$n_{\text {(stored) }} \quad$ Broj zauzetih skladišnih lokacija

$F \quad$ Funkcija raspodele

$E \quad$ Očekivana vrednost

$P \quad$ Verovatnoća

$\alpha \quad$ Faktor popunjenosti skladišta

$t \quad$ Promenljivo vreme saobraćanja dizalice

$T_{(S C)} \quad$ Jednostruki ciklus

$T_{(D C)} \quad$ Dvostruki ciklus

$t_{1} \quad$ Vreme uskladištenja/iskladištenja u prvom paletnom nizu

$t_{2} \quad$ Vreme uskladištenja/iskladištenja u drugom paletnom nizu

\subsection{Kretanje dizalice}

Vreme kretanja dizalice do bilo koje slučajno izabrane lokacije u regalu je slučajna promenljiva, koja zavisi od tehničkih krakteristika dizalice, dužine i visine regala i strategije rada sistema. Vreme saobraćanja $t_{x y}$ od I/O lokacije do bilo koje slučajno izabrane lokacije u regalu, je veća vrednost od $t_{x}$ ili $t_{y}$, gde je $t_{x}$ vreme kretanja u horizontalnom pravcu, a $t_{y}$ vreme kretanja u vertikalnom pravcu. Prema usvojenoj strategiji o ravnomernoj raspodeli korišćenja svih lokacija u regalu i uslovu da su $x$ i $y$ koordinate lokacija nezavisne, mogu se naći funkcije raspodela verovatnoća $F_{x}(t)$ i $F_{y}(t)$. One se razlikuju po profilu ostvarenih brzina: tipu I, kada je vršna brzina manja od $v_{\max }$, tipu II, kada je vršna brzina jednaka $v_{\max }$.

3.1.1 Kretanje dizalice u horizontalnom pravcu i kretanje podiznog stola od I/O do bilo koje slučajno izabrane lokacije u regalu

Kretanje dizalice u horizontalnom pravcu dato je izrazom H. Hwang i S. B. Lee [7]:

$$
F_{x}(t)=\left\{\begin{array}{c}
\frac{a_{x} t^{2}}{4 L}\left(0 \leq t \leq \frac{2 v_{x}}{a_{x}}\right) \\
\frac{v_{x} t}{L}-\frac{v_{x}^{2}}{a_{x} L}\left(\frac{2 v_{x}}{a_{x}} \leq t \leq \frac{L}{v_{x}}+\frac{v_{x}}{a_{x}}\right)
\end{array}\right.
$$

Kretanje podiznog stola u vertikalnom pravcu dato je izrazom H. Hwang i S. B. Lee [7]:

$$
F_{y}(t)=\left\{\begin{array}{c}
\frac{a_{x} t^{2}}{4 H}\left(0 \leq t \leq \frac{2 v_{y}}{a_{y}}\right) \\
\frac{v_{y} t}{H}-\frac{v_{y}{ }^{2}}{a_{y} H}\left(\frac{2 v_{y}}{a_{y}} \leq t \leq \frac{H}{v_{y}}+\frac{v_{y}}{a_{y}}\right)
\end{array}\right.
$$




\subsubsection{Kretanje dizalice u horizontalnom pravcu i kretanje podiznog stola od skladišne lokacije do bilo koje slučajno izabrane lokacije}

iskladištenja u regalu

Kretanje dizalice u horizontalnom pravcu dato je izrazom, H. Hwang i S. B. Lee [7]:

$$
F_{x}(t)=\left\{\begin{array}{c}
\frac{a_{x}}{2 L} t^{2}-\frac{a_{x}^{2}}{16 L^{2}} t^{4}\left(0 \leq t \leq \frac{2 v_{x}}{a_{x}}\right) \\
-\frac{v_{x}^{2}}{L^{2}} t^{2}+\left[\frac{2 v_{x}^{3}}{a_{x} L^{2}}+\frac{2 v_{x}}{L}\right] t-\frac{2 v_{x}^{2}}{a_{x} L}-\frac{v_{x}^{4}}{a_{x}^{2} L^{2}}\left(\frac{2 v_{x}}{a_{x}} \leq t \leq \frac{L}{v_{x}}+\frac{v_{x}}{a_{x}}\right)
\end{array}\right.
$$

Kretanje podiznog stola u vertikalnom pravcu dato je izrazom, H. Hwang i S. B. Lee [7]:

$$
F_{y}(t)=\left\{\begin{array}{c}
\frac{a_{y}}{2 H} t^{2}-\frac{a_{y}^{2}}{16 H^{2}} t^{4}\left(0 \leq t \leq \frac{2 v_{y}}{a_{y}}\right) \\
-\frac{v_{y}^{2}}{H^{2}} t^{2}+\left[\frac{2 v_{y}^{3}}{a_{y} H^{2}}+\frac{2 v_{y}}{H}\right] t-\frac{2 v_{y}^{2}}{a_{y} H}-\frac{v_{y}{ }^{4}}{a_{y}^{2} H^{2}}\left(\frac{2 v_{y}}{a_{y}} \leq t \leq \frac{H}{v_{y}}+\frac{v_{y}}{a_{y}}\right)
\end{array}\right.
$$

Fukcija raspodele verovatnoća $F_{i k}(t)$ (gde je $i=1$ ili $2 ; k=1, \ldots$, б) zavisi od odnosa između parametara $v_{x}, v_{y}, a_{x}, a_{y}, L, H$. Tako se $F_{i k}(t)$ može specificirati za teoretski 6 različitih slučajeva, T. Lerher i ost. [23]:

$$
F_{i k}(t)=F_{x}(t) \cdot F_{y}(t) \text { за } 0 \leq t \leq T
$$

gde $F_{l k}(t)$ odgovara kretanju dizalice u horizontalnom pravcu i kretanju podiznog stola od I/O do bilo koje slučajno izabrane lokacije u regalu, a $F_{2 k}(t)$ odgovara kretanju dizalice u horizontalnom pravcu i kretanju podiznog stola od skladišne lokacije do bilo koje slučajno izabrane lokacije iskladištenja.

Očekivano vreme kretanja $E_{i k}(t)$ odgovara $k$-tom uslovu i jednako je, T. Lerher i ost. [23]:

$$
E_{i k}(t)=\int_{0}^{\max \left(T_{x}, T_{y}\right)}\left(1-F_{i k}(t)\right) \mathrm{d} t
$$

U regalima dvostruke dubine prosečno vreme kretanja u dvostrukim ciklusima je uvećano za vreme premeštanja TJ koja blokira pristup željenoj lokaciji, na najbližu slobodnu lokaciju u regalu.

Očekivane vrednosti rastojanja od lokacije blokirane TJ, do slobodne lokacije u horizontalnom $E_{x}$, i u vertikalnom pravcu $E_{y}$, dato je sledećim izrazom, T. Lerher i ost. [23]:

$$
E_{x}=\frac{1}{3} \cdot \frac{L}{n_{x}} \sqrt{\frac{1}{(1-\alpha)}} ; E_{y}=\frac{1}{3} \cdot \frac{H}{n_{y}} \sqrt{\frac{1}{(1-\alpha)}}
$$

Faktor $\alpha$ određuje se iz izraza:

$$
\alpha=\frac{n_{\text {stored TUL }}}{\left(n_{x} \cdot n_{y}\right)_{\text {total TUL }}}
$$

Na slici 1 prikazana je dispozicija regala pri faktoru $\alpha(0.5,1)$ i situaciji premeštanja TJ koja blokira pristup željenoj lokaciji.

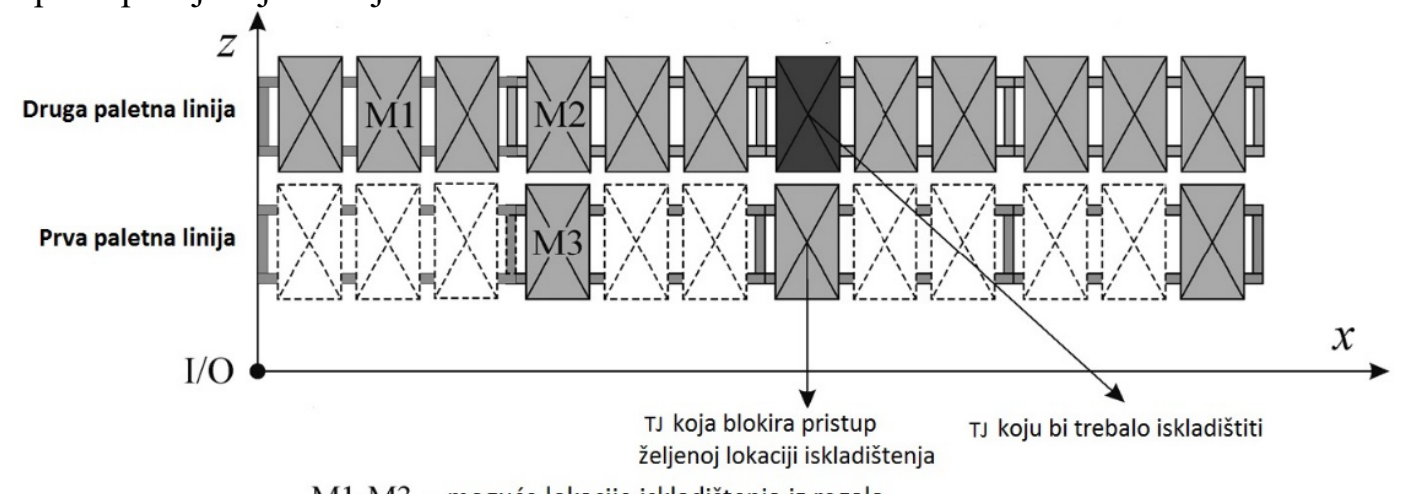

M1-M3 - moguće lokacije iskladištenja iz regala

Slika 1 - Dispozicija regala pri faktoru $\alpha(0.5,1)$ i situaciji premeštanja TJ koja blokira pristup željenoj lokaciji 
[23]:

Očekivano vreme jednostrukog ciklusa $E(S C)$ pri uskladištenju dato je izrazom, T. Lerher i ost.

$$
E(S C)=t_{P D}+2 \cdot E\left(t_{p_{i}, p_{i}+1}\right)+t_{1}
$$

gde je $t_{P D}$ vreme utovara/istovara TJ u I/O lokaciji, $\mathrm{E}\left(t_{p_{i}, p_{i+1}}\right)$ vreme kretanja od I/O $\left(p_{i}\right)$ do odredišne tačke $\left(p_{i+1}\right)$ i $t_{1}$ vreme istovara/utovara $\mathrm{TJ}$ u prvom paletnom nizu regala.

Ukoliko je pri izuzimanju TJ blokirana, očekivano vreme jednostukog ciklusa $E$ (SC) dato je izrazom, T. Lerher i ost. [23]:

$$
\begin{gathered}
E(S C)=E(S C)+\frac{\alpha}{2} E(R) \\
E(S C)=t_{P D}+2 \cdot E\left(t_{p_{i}, p_{i}+1}\right)+\left(P_{1} \cdot t_{1}+P_{2} \cdot t_{2}\right)+\frac{\alpha}{2}\left[2 \cdot E\left(t_{R}\right)+2 t_{1}\right]
\end{gathered}
$$

gde je:

$P_{l}$ - verovatnoća izuzimanja TJ iz prvog paletnog niza,

$P_{2}$ - verovatnoća izuzimanja TJ iz drugog paletnog niza,

$t_{2}$ - vreme istovara/utovara $\mathrm{TJ} \mathrm{u}$ drugom paletnom nizu regala,

$T R$ - vreme kretanja dizalice od lokacije iskladištenja do slobodne lokacije odlaganja TJ koja blokira željenu TJ na lokaciji iskladištenja.

Verovatnoće $P_{1}$ i $P_{2}$ date su izrazima:

$$
P_{1}=\frac{2 \alpha-1}{2 \alpha} ; P_{2}=\frac{1}{2 \alpha}
$$

Očekivano vreme jednostukog ciklusa $E$ (SC) dobija se kao, T. Lerher i ost. [23]:

$$
E(S C)=t_{P D}+2 \cdot E\left(t_{p_{i}, p_{i+1}}\right)+\left(\left(\frac{2 \alpha-1}{2 \alpha}\right) \cdot t_{1}+\left(\frac{1}{2 \alpha}\right) \cdot t_{2}\right)+\frac{\alpha}{2}\left[2 \cdot E_{\left(t_{R}\right)}+2 \cdot t_{2}\right]
$$

Očekivano vreme dvostrukog ciklusa $E(D S) M$ dato je izrazom, T. Lerher i ost. [23]:

$$
E(D C)=2 t_{P D}+2 \cdot E\left(t_{p_{i}, p_{i+1}}\right)+t_{1}+E\left(t_{p_{i+1}, p_{i+2}}\right)+\left(\left(\frac{2 \alpha-1}{2 \alpha}\right) \cdot t_{1}+\left(\frac{1}{2 \alpha}\right) \cdot t_{2}\right)+\frac{\alpha}{2}\left[2 \cdot E_{\left(t_{R}\right)}+2 \cdot t_{2}\right]
$$

gde je $\mathrm{E}\left(t_{p_{i+1}, p_{i+2}}\right)$ vreme kretanja od lokacije uskladištenja $p_{i+1}$, do lokacije iskladištenja $p_{i+2}$.

\section{Model za određivanje srednjeg vremena ciklusa (mini-load $A S / R S)$ u kome dizalica nosi više TJ istovremeno}

Model se zasniva na sledećim pretpostavkama, R. D. Meller i A. Mungwatana [14]:

- regal se posmatra kao kontinualna pravougaona površina dužine $L$ i visine $H$. Lokacija u kojoj TJ ulaze i izlaze iz regala (I/O) se nalazi u donjem levom uglu,

- pretpostavlja se slučajno korišćenje lokacija u regalu, tj. regal je približno $100 \%$ iskorišćen. Bilo koja lokacija u regalu se može koristiti za lokaciju uskladištenja i iskladištenja,

- dizalica saobraća istovremeno se krećući u horizontalnom i vertikalnom pravcu. Pri izračunavanju vremena saobraćanja, usvaja se konstantna brzina $v_{h}$ u horizontalnom, i $v_{v} \mathrm{u}$ vertikalnom pravcu.

Pri navedenim pretpostavkama i korišćenjem FIFO discipline u redu čekanja, jednosmerno vreme saobraćanja (SA), jednostruki ciklus (SC), vreme saobraćanja između lokacije uskladištenja i iskladištenja (TB) i vreme dvostukog ciklusa (DC), određuje se kao, A. Y. Bozer i A. J. White [4], R. D. Meller i A. Mungwatana [14]:

1. Izračunati dimenzije regala svedene na vreme saobraćanja, kao: $t_{h}=L / v_{h}$ i $t_{v}=H / v_{v}$

2. Neka je $T$ faktor skaliranja, a $b$ faktor oblika regala, gde je $T=\max \left(t_{h}, t_{v}\right), b=\min \left(t_{h} / T, t_{v} / T\right)$.

Funkcija raspodele verovatnoće $F(z)$ i gustina raspodele $f(z)$ saobraćanja između bilo koje dve tačke u regalu date su izrazima:

$$
\begin{aligned}
& f(z)= \begin{cases}(2-2 z)\left[2\left(\frac{z}{b}\right)-\left(\frac{z}{b}\right)^{2}\right]+\left(2 z-z^{2}\right)\left[\frac{2}{b}-\frac{2 z}{b^{2}}\right] & \text { ako je } 0 \leq z \leq b \\
2-2 z & \text { ako je } b \leq z \leq 1\end{cases} \\
& F(z)= \begin{cases}\left(2 z-z^{2}\right)\left[2\left(\frac{z}{b}\right)-\left(\frac{z}{b}\right)^{2}\right] & \text { ako je } 0 \leq z \leq b \\
2-z^{2} & \text { ako je } b \leq z \leq 1\end{cases}
\end{aligned}
$$




\subsection{Očekivano vreme saobraćanja pri šestostrukim ciklusima (STC) i NN strategiji}

Pretpostavljajući da je primenjena $N N$ strategija i pri STC, (STC NN) očekivano vreme saobraćanja se može izračunati kao, R. D. Meller i A. Mungwatana [14]:

1. Pri tri slobodne skladišne lokacije (npr. $s_{1}, s_{2}$ i $s_{3}$ ) skladišna dizalica saobraća od I/O stanice do najbliže skladišne lokacije, npr. $s_{l}$. Očekivano vreme saobraćanja od I/O do $s_{l}$, jednako je očekivanom najkraćem vremenu jednosmernog saobraćanju pri tri slobodne lokacije, tj. za $m=3$ dobijamo:

$$
E\left(S W_{I / O}^{S}\right)=E\left(S W_{(m=3)}\right)=\left[\frac{1}{4}+\frac{b^{2}}{2}-\frac{2 b^{3}}{5}+\frac{3 b^{4}}{28}\right]
$$

2. Posle prvog uskladištenja, dizalica se kreće do sledeće lokacije uskladištenja, recimo $s_{2}$, budući da je $s_{2}$ bliža $s_{1}$, nego $s_{3}$. Očekivano vreme saobraćanja između $s_{1}$ i $s_{2}$, se procenjuje kao očekivano najkraće vreme saobraćanja između bilo koje dve lokacije u regalu i $m=2$ mogućih lokacija, dobijamo:

$$
E\left(T B_{s 1}^{s 2}\right)=E\left(T B_{(m-1=2)}\right)=\left[\frac{b^{2}}{3}-\frac{31 b^{3}}{105}+\frac{5 b^{4}}{42}-\frac{11 b^{5}}{630}+\frac{1}{5}\right]
$$

3. Dizalica se kreće do poslednje lokacije uskladištenja. Očekivano vreme saobraćanja između $s_{2}$ i $s_{3}$, se procenjuje kao očekivano najkraće vreme saobraćanja kada dizalica nosi samo jednu TJ, A. Y. Bozer i A. J. White [4], R. D. Meller i A. Mungwatana [14]:

$$
E\left(T B_{s 2}^{S 3}\right)=E\left(T B_{m-2=1}\right)=\left[\frac{1}{3}+\frac{b^{2}}{6}-\frac{b^{3}}{30}\right]
$$

4. Od skladišne lokacije dizalica se kreće do najbliže od tri lokacije iskladištenja $\left(r_{1}, r_{2} \mathrm{i} r_{3}\right)$, npr. $r_{l}$. Očekivano vreme saobraćanja između $s_{3}$ i $r_{l}$, za $m=3$, može se dobiti iz izraza:

$$
E\left(T B_{s 3}^{r 1}\right)=E\left(T B_{m}\right)=\int_{0}^{1} m z[1-F(z)]^{m-1} f(z) d z
$$

5. Od prve lokacije iskladištenja, $r_{l}$, dizalica se kreće do bliže lokacije, od preostale dve lokacije iskladištenja, recimo $r_{2}$. Očekivano vreme saobraćanja između $r_{1}$ i $r_{2}$, se procenjuje kao očekivano najkraće vreme saobraćanja između $s_{1}$ i $s_{2}$, tj. kao minimalno od dva vremena saobraćanja između bilo koje dve lokaciju u regalu, tj.

$$
E\left(T B_{r 1}^{r 2}\right)=E\left(T B_{2}\right)=\left[\frac{b^{2}}{3}-\frac{31 b^{3}}{105}+\frac{5 b^{4}}{42}-\frac{11 b^{5}}{630}+\frac{1}{5}\right]
$$

6. Dizalica potom, saobraća do poslednje lokacije iskladištenja $r_{3}$. Očekivano vreme saobraćanja između $r_{2}$ i $r_{3}$, se procenjuje kao i očekivano najkraće vreme saobraćanja između $s_{2}$ i $s_{3}$, tj. kao

$$
E\left(T B_{r 2}^{r 3}\right)=E(T B)=\left[\frac{1}{3}+\frac{b^{2}}{6}-\frac{b^{3}}{30}\right]
$$

7. Na kraju, dizalica se vraća u I/O stanicu. Očekivano vreme saobraćanja između $r_{3}$ i I/O stanice, se procenjuje kao i očekivano najkraće vreme jednosmernog saobraćanja između $s_{2}$ i $s_{3}$,

$$
E\left(S A_{r 3}^{I / O}\right)=E(S A)=\left[\frac{1}{2}+\frac{b^{2}}{6}\right]
$$

Dakle, očekivano ukupno vreme STC sa $N N$ strategijom može se proceniti, kao R. D. Meller i A. Mungwatana [14]:

$$
\begin{aligned}
E\left(S T C^{N N}\right)= & E\left(S W_{(m=3)}\right)+E\left(T B_{(m-1=2)}\right)+E\left(T B_{(m-2=1)}\right)+ \\
& +E\left(T B_{3}\right)+E\left(T B_{2}\right)+E(T B)+E(S A)
\end{aligned}
$$

Izloženi analitički model predstavljen je za $m=3$, tri slobodne (moguće) lokacije skladišnih operacija, ali se može generalizovati na $m$ slobodnih lokacija. 


\section{Automatska skladišta opsluživana skladišnim vozilima koja transportuju male terete - kontejnere $(S B S / R S)$}

Karakteristični $(A S / R S)$ ove vrste sastoje se od skladišnih regala za plastične kontejnere, lifta u svakom skladišnom hodniku i skladišnih vozila, koja se kreću na svakom skladišnom nivou, slike 2 i 3.

Visina regala može biti i preko $20 \mathrm{~m}$, a širina kontejnera je oko $0.5 \mathrm{~m}$. Liftovi se sastoje od stuba sa dva nezavisna podizna stola koja istovremeno mogu podizati i spuštati kontejnere, čime se povećava kapacitet protoka kontejnera kroz sistem. Po izlasku iz lifta kontejneri se na skladišnim nivoima odlažu na akumulacioni transporter naspram regala. Na svakom nivou nalazi se vozilo koje uskladištuje i iskladištuje kontejnere. Vozila uvek ostaju na svom skladišnom nivou, pa je „usko grlo“ u sistemu najčešće lift. Osnovne prednosti $(S B S / R S)$ su: moguće lako buduće proširenje sistema, optimalno iskorišćenje prostora usled malih dimenzija potrebnih za opsluživanje krajnjih skladišnih lokacija u regalu i visok kapacitet protoka kontejnera kroz sistem u poređenju sa (mini-load $A S / R S$ ).

Pri razvoju analitičkih modela za izračunavanja vremena saobraćanja, usvojene su sledeće pretpostavke, slike 2 i 3, T. Lerher i ost. [30]:

- lokacija ulaska/izlaska kontejnera (I/O) nalazi se na prvom skladišnom nivou, do lokacije lifta,

- na svakom skladišnom nivou nalaze se dva akumulaciona transportera i jedno skladišno vozilo,

- lift poseduje dva podizna stola koja nezavisno opslužuju po jedan kontejner,

- lift i skladišno vozilo saobraćaju po jednostrukim SCC ili dvostrukim ciklusima DCC,

- brzina i ubrzanje $\left(v_{y}, a_{y}\right)$ podiznih stolova lifta i visina regala $H$ su prethodno poznati,

- brzina i ubrzanje $\left(v_{x}, a_{x}\right)$ skladišnih vozila i dužina regala $L$ su prethodno poznati,

- visina $H$ i dužina $L$ regala su dovoljno veliki, da skladišno vozilo i podizni stolovi postignu maksimalnu brzinu $v_{\max } \mathrm{u}$ vertikalnom i horizontalnom pravcu,

- usvojeno je pravilo slučajnog dodeljivanja lokacije uskladištenja i iskladištenja, tj. svaka lokacija u regalu ima istu verovatnoću da će biti izabrana za mesto uskladištenja ili iskladištenja.

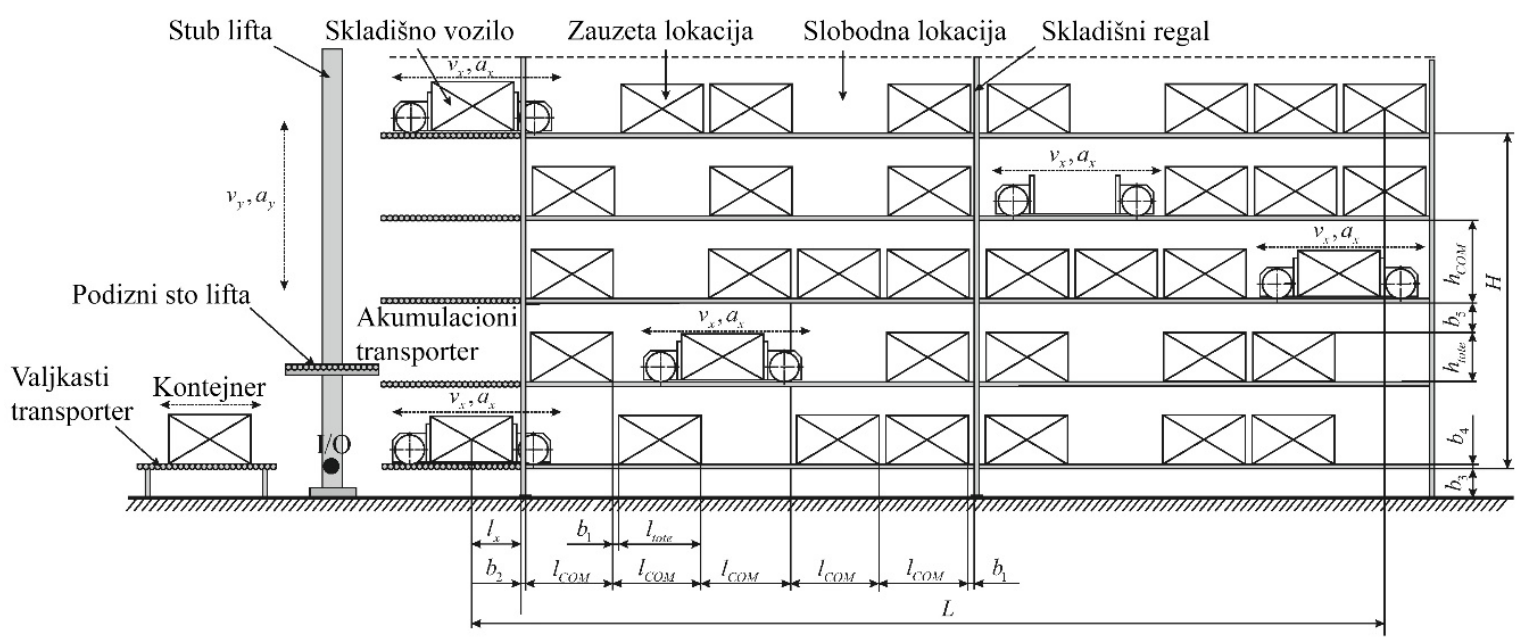

Slika 2 - (SBS/RS) sa skladišnim vozilima koja ne napuštaju regalni nivo

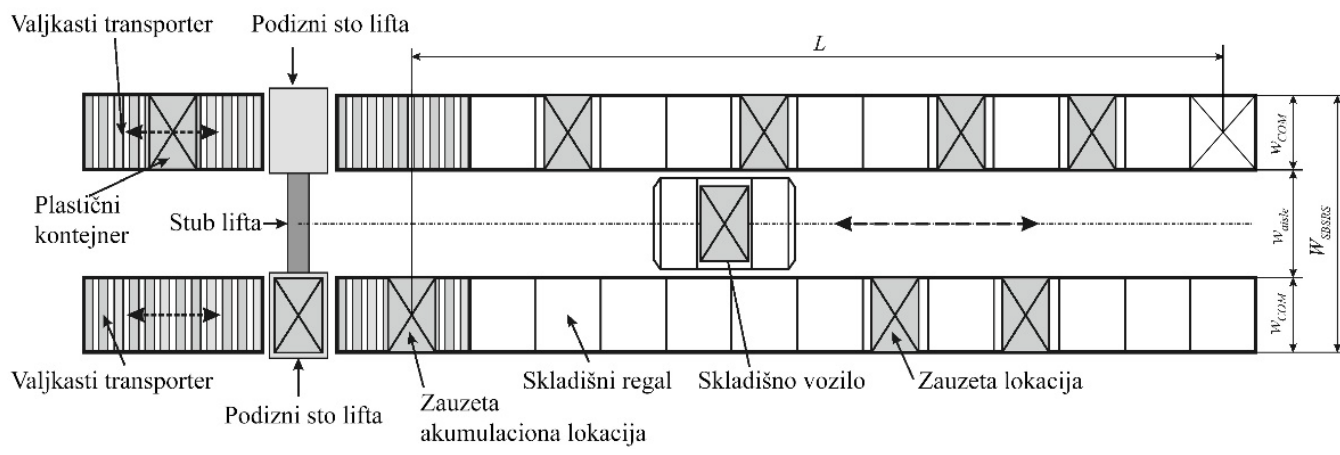

Slika 3 - (SBS/RS) sa liftom sa dva podizna stola

U modelu se koriste sledeće oznake: 


$\begin{array}{ll}a & \text { Ubrzanje/usporenje } \\ a_{y} & \text { Ubrzanje/usporenje podiznih stolova lifta } \\ a_{y+} & \text { Ubrzanje podiznih stolova lifta } \\ T & \text { Ukupno vreme saobraćanja do određene lokacije } \\ F_{(k)} & \text { Funkcija raspodele } \\ a_{y-} & \text { Usporenje podiznih stolova lifta } \\ s(t) & \text { Pređeni put (pomeraj) u fukciji vremena } \\ d(T) & \text { Pređeni put za vreme } T \\ \mathrm{E}(\mathrm{ES})_{\text {LIFT }} & \text { Očekivano vreme jednosmernog saobraćanja podiznog stola lifta } \\ \mathrm{E}(\mathrm{SCC})_{\text {LIFT }} & \text { Očekivano vreme jednostrukog ciklusa podiznog stola lifta } \\ \mathrm{E}(\mathrm{TB})_{\text {LIFT }} & \text { Očekivano vreme saobraćanja podiznog stola lifta između lokacija uskladištenja i } \\ & \text { iskladištenja } \\ \mathrm{E}(\mathrm{DCC})_{\mathrm{LIFT}} & \text { Očekivano vreme dvostukog ciklusa podiznog stola lifta } \\ \alpha & \text { Faktor popunjenosti regala } \\ H & \text { Visina poslednjeg regalnog nivoa } \\ L & \text { Maksimalna dužina saobraćanja u regalu } \\ v_{y} & \text { Maksimalna brzina podiznog stola lifta u vertikalnom pravcu } \\ v_{\max } & \text { Maksimalna brzina } \\ h & \text { Minimalno rastojanje potrebno za ostvarivanje } v_{y} \\ v\left(t_{p}\right) & \text { Maksimalna brzina u trenutku vremena } t_{p} \\ t_{\mathrm{P} / \mathrm{S}} & \text { Vreme utovara/istovara kontejnera sa podiznog stola lifta i skladišnog vozila } \\ t_{y} & \text { Vreme potrebno podiznom stolu lifta da postigne } h \\ T_{y} & \text { Vreme potrebno podiznom stolu lifta da postigne visinu } H \\ t_{p} & \text { Vreme potrebno da se postigne maksimalna brzina } \\ v(t) & \text { Brzina u funkciji vremena }\end{array}$

\subsection{Analitički model kretanja u (SBS/RS)}

Kretanje podiznog stola lifta i skladišnog vozila se ostvaruje u dva profila brzina, u zavisnosti da li je ostvarena vršna brzina $v_{t}$ ) manja od maksimalne $v_{\max }$, (tip I) ili jednaka maksimalnoj, (tip II). Može se pokazati da je $T<2 v_{\max } / a$, za tip I i $T>2 v_{\max } / a$, za tip II, T. Lerher i ost. [30], slika 4.
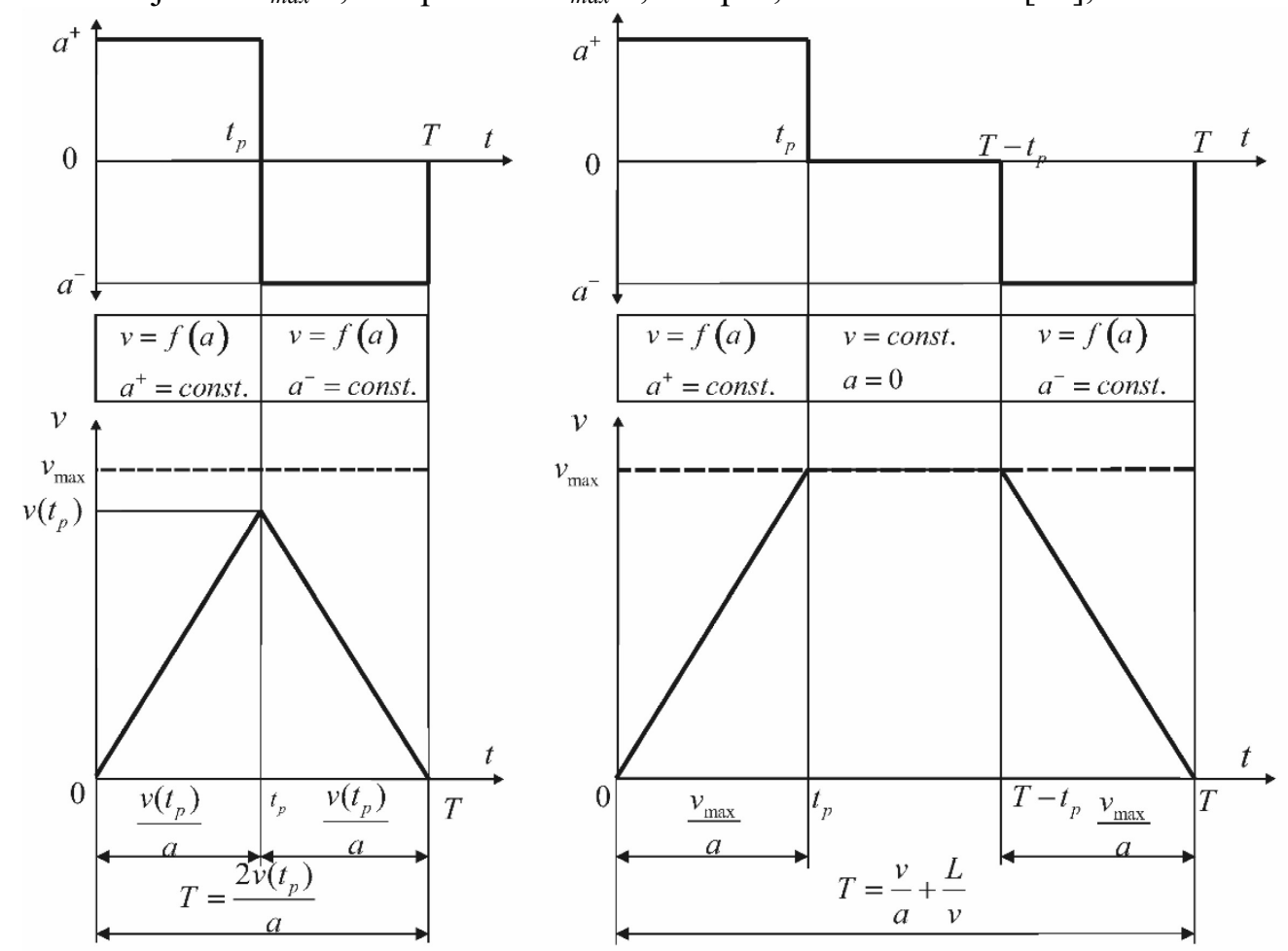

Slika 4 - Profili brzina (tipovi brzina) 


\subsubsection{Kretanje po tipu I $\left(T<2 v_{\max } / a\right)$}

Brzina u zavisnosti od vremena $v_{(t)}$ može se izraziti kao:

$$
v(t)=\left\{\begin{array}{c}
a t, t \in\left(o, t_{p}\right) \\
-a(t-T), t \in\left(t_{p}, T\right)
\end{array}\right.
$$

Pređeni put (rastojanje) u zavisnosti od vremena, $d(T)$ jednako je:

$$
d(T)=\int_{0}^{T} v(t) \mathrm{d} t=\frac{a T^{2}}{4}
$$
$t_{p}=T / 2$.

Budući da su ubrzanje i usporenje jednaka, vreme potrebno da se ostvari vršna brzina jednako je

$$
\text { 5.1.2 Kretanje po tipu II }\left(T>2 v_{\max } / a\right)
$$

Brzina u zavisnosti od vremena $v(t)$ može se izraziti kao:

$$
v(t)=\left\{\begin{array}{c}
a t, t \in\left(o, t_{p}\right) \\
v_{\text {max }}, t \in\left(t_{p}, T-t_{p}\right) \\
-a(t-T), t \in\left(T-t_{p}, T\right)
\end{array}\right.
$$

Pređeni put (rastojanje) u zavisnosti od vremena, $d(T)$ jednako je:

$$
\mathrm{d}(T)=\int_{0}^{T} v(t) \mathrm{d} t=v_{\max } T-\frac{v_{\max }{ }^{2}}{a}
$$

\subsection{Jednostruki ciklus podiznog stola lifta u vertikalnom pravcu u (SBS/RS)}

Pri SCC ostvaruje se uskladištenje ili iskladištenje kontejnera. Pri SCC podizni sto podiže kontejner na $i$-ti nivo regala, istovaruje kontejner i vraća se nazad u I/O lokaciju. Isti niz operacija se može odvijati i u suprotnom smeru. Vreme jednosmernog saobraćanja (ES) LIFT predstavlja promenljivo vreme $t$ potrebno za podizanje kontejnera od I/O lokacije do željenog $i$-tog nivoa regala. $\mathrm{Na}$ osnovu pretpostavke o ravnomernoj raspodeli verovatnoća opsluživanja svih regalnih nivoa, dobija se funkcija raspodele kretanja (pređenog puta) $F_{y}(t)$, koja zavisi od profila ostvarenih brzina, T. Lerher i ost. [30]: $h=v_{y}{ }^{2} / a_{y}$.

(a) Kretanje podiznog stola lifta po tipu I, gde je $t_{y}=2 v_{y} / a_{y}$ vreme potrebno da se postigne visina visina $H$.

(b) Kretanje podiznog stola lifta po tipu II, gde je $T_{y}=H / v_{y}+v_{y} / a_{y}$ vreme potrebno da se postigne

Funkcija raspodele kretanja $F_{y}(t)$ data je izrazom, T. Lerher i ost. [30]:

$$
F_{y}(t)=\left\{\begin{array}{c}
\frac{t^{2} a_{y}}{4 H},\left(0 \leq t \leq \frac{2 v_{y}}{a_{y}}\right) \\
\frac{v_{y} t}{H}-\frac{v_{y}^{2}}{a_{y} H},\left(\frac{2 v_{y}}{a_{y}} \leq t \leq \frac{H}{v_{y}}+\frac{v_{y}}{a_{y}}\right)
\end{array}\right.
$$

Funkcija raspodele vremena kretanja $F(t)$ zavisi od odnosa parametara $v_{y}, a_{y}$ i $H$. Dakle, $F(t)$ može se specificirati pod sledećim uslovima, T. Lerher i ost. [30]:

$$
F(t)=F_{y}(t),\left(0 \leq t \leq T_{y}\right)
$$

Očekivano vreme jednosmernog kretanja podiznog stola lifta $\mathrm{E}(\mathrm{ES})_{\mathrm{LIFT}}$ dobija se po sledećem izrazu, T. Lerher i ost. [30]:

$$
E(E S)_{L I F T}=\int_{0}^{T_{y}}(1-F(t)) \mathrm{d} t
$$

Očekivano vreme jednostrukog ciklusa u $(S B S / R S)$ dobija se kao, T. Lerher i ost. [30]:

$$
E(S C C)_{L I F T}=2 t_{P / S}+2 E(E S)_{L I F T}
$$

\subsection{Dvostruki ciklus podiznog stola lifta u vertikalnom pravcu u (SBS/RS)}

U DCC ostvaruje se uskladištenje i, potom, odmah iskladištenje kontejnera. Pri DCC podizni sto podiže kontejner na $i$-ti nivo regala, istovaruje kontejner i potom saobraća do $j$-tog nivoa, gde utovaruje kontejner. Po utovaru, sa j-tog nivoa, podizni sto lifta vraća se u I/O lokaciju. Vreme 
kretanja pri DCC odgovara vremenu kretanja za SCC do slučajno izabranog i-tog regalnog nivoa, kome se pridodaje vreme saobraćanja između lokacije uskladištenja i iskladištenja (TB) $)_{\text {LIFT }}$. Po definiciji DCC sadrži dva slučajno izabrana regalna nivoa $i$ - $t i$ (uskladištenje) $i j$ - $t i$ (iskladištenje).

Na osnovu pretpostavke o ravnomernoj raspodeli verovatnoća opsluživanja svih regalnih nivoa, dobija se funkcija raspodele kretanja (pređenog puta) $F_{y}(t)$, koja zavisi od profila ostvarenih brzina: $h=v_{y}^{2} / a_{v}$.

(a) Kretanje podiznog stola lifta po tipu I, gde je $t_{y}=2 v_{y} / a_{y}$ vreme potrebno da se postigne visina visina $H$

(b) Kretanje podiznog stola lifta po tipu II, gde je $T_{y}=H / v_{y}+v_{y} / a_{y}$ vreme potrebno da se postigne

Funkcija raspodele kretanja u vertikalnom pravcu $F y(t)$ može se specificirati pod sledećim uslovima, T. Lerher i ost. [30]:

$$
F_{y}(t)=\left\{\begin{array}{c}
\frac{a_{y}}{2 H} t^{2}-\frac{a_{y}{ }^{2}}{16 H^{2}} t^{4},\left(0 \leq t \leq \frac{2 v_{y}}{a_{y}}\right) \\
-\frac{v_{y}^{2}}{H^{2}} t^{2}+\left[\frac{2 v_{y}^{3}}{a_{y} H^{2}}+\frac{2 v_{y}}{H}\right] t-\frac{2 v_{y}^{2}}{a_{y} H}-\frac{v_{y}{ }^{4}}{a_{y}^{2} H^{2}},\left(\frac{2 v_{y}}{a_{y}} \leq t \leq \frac{H}{v_{y}}+\frac{v_{y}}{a_{y}}\right)
\end{array}\right.
$$

Funkcija raspodele vremena kretanja $F(t)$ zavisi od odnosa parametara $v_{y}, a_{y}$ i $H$. Dakle, $F(t)$ može se specificirati pod sledećim uslovima, T. Lerher i ost. [30]:

$$
F(t)=F_{y}(t),\left(0 \leq t \leq T_{y}\right)
$$

Očekivano vreme kretanja podiznog stola lifta između lokacija uskladištenja i iskladištenja, $\mathrm{E}(\mathrm{TB})_{\mathrm{LIFT}}$ pri DCC za dva slučajno izabrana regalna nivoa $i \mathrm{i} j$, jednake je sledećem izrazu, T. Lerher $\mathrm{i}$ ost. [30]:

$$
E(T B)_{L I F T}=\int_{0}^{T_{y}}(1-F(t)) \mathrm{d} t
$$

Očekivano vreme DCC u $(S B S / R S)$ dobija se kao, T. Lerher i ost. [30]:

$$
E(D C C)_{L I F T}=2 t_{P / S}+E(S C C)_{L I F T}+E(T B)_{L I F T}
$$

$\mathrm{Na}$ isti način dobijaju se potrebni izrazi za izračunavanje vremena ciklusa skladišnog vozila.

\section{Zaključak}

$\mathrm{U}$ radu su dati osnovni tipovi $(A S / R S)$ koje se koriste u farmaceutskoj industriji. Predstavljene su i neke osnovne smernice za projektovanje $(A S / R S)$ u farmaceutskoj industriji: vrste skladištenog materijala, uslovi čuvanja materijala, osnovne karakteristike podsistema za prijem materijala, osnovne karakteristike podsistema za komisioniranje, zahtevani ambijentalni uslovi (temperature, čistoća vazduha, nivo filtracije vazduha). U novije vreme, opšti trend smanjenja troškova u logistici primorao je distributere farmaceutskih proizvoda da snabdevaju i mnoge klijente koji zahtevaju frekventnije, ali $\mathrm{u}$ isto vreme veoma male porudžbine. Usled izuzetne važnosti rešavanja ovog problema, predstavljeni su analitički modeli za određivanje očekivanih vremena ciklusa kod (miniload $A S / R S)$ i $(S B S / R S)$ sistema, koja definišu protok TJ kroz sistem, najvažniju performansu sistema. $\mathrm{U}$ isto vreme, predstavljen je i analitički model za određivanje očekivanih vremena ciklusa dizalice kod (unit-load $A S / R S$ ) sa regalima dvostruke dubine, budući da je ovo, verovatno, najčešće korišćena tehnologija skladištenja u podsistemu glavnog skladišta u farmaceutskim fabrikama. Svi navedeni modeli mogu poslužiti projektantima i inženjerima koji se ovim problemima bave u praksi, kao i proizvođačima ovih sistema, da odrede meru uspešnosti projektnih rešenja, odnosno, da garantuju potencijalnim korisnicima najvažnije performanse sistema.

\section{Literatura}

[1] Lerher, T., Throughput and energy related performance calculation for shuttle based storage and retrieval systems, Nuova Science Publishers, New York, ISBN: 978-1-63483-431-5, 2016.

[2] Hausman, W. H., Schwarz L. B., Graves, S. C., Optimal storage assignment in automatic warehousing systems, Management science, 22(6), 629-638, 1976.

[3] Graves, S. C., Hausman, W. H., Schwarz, L. B., Storage retrieval interleaving in automatic warehousing systems, Management science 23(9), 935-945, 1977. 
[4] Bozer, A. Y., White, A. J., Travel-Time Models for Automated Storage and Retrieval Systems, IIE Transactions, 16(4), 329-338, 1984.

[5] Han, M. H., McGinnis, F. L., On sequencing Retrievals in an Automated storage and retrieval system, Material Handling Research Center, IIE Transactions, 19(1), 56-66, 1987.

[6] Gudehus T, Principles of order picking: operations indistribution and warehousing systems. Essen, Germany, 1973.

[7] Hwang, H., Lee, S. B., Travel time models considering the operating characteristics of the storage and retrieval machine, International Journal of Production Research, 28(10), 1779-1789, 1990.

[8] Vössner, S., Spielzeitberechnung von Regalförderzeugen (Traveltime calculation of storage and retrieval machines), Ph.D. dissertation, Graz University of Technology, 1994.

[9] Vidovic, M., Die Systemanalyse und Umschlagleistungen von Regalförderzeugen mit Mehrfachlastaufnahmemitteln (System analysis and throughput of storage and retrieval machines with multiple load handling devices), Ph.D. dissertation, Graz University of Technology, 1994.

[10] Hwang, H., Ko, S. C., A study on multi-aisle system served by a single storage/retrieval machine, International Journal of Production Research, 26(11), 1727-1737, 1988.

[11] Lerher, T., Sraml, M., Kramberger, J., Potrc, I., Borovinsek, M., Zmazek, B., Analytical travel time models for multi aisle automated storage and retrieval systems. The international journal of advanced manufacturing technology, 30(3-4), 340-356, 2005.

[12] Lerher, T., Potrc, I., Sraml, M., Tollazzi, T., Travel time models for automated warehouses with aisle transferring storage and retrieval machine, European journal of operational research, 205(3), 571-583, 2010.

[13] Keserla, A., Peters, A. B., Analysis of dual-shuttle automated storage/retrieval systems, Journal of Manufacturing Systems, 13(6), 424-434, 1994.

[14] Meller DR, Mungwatana A., Multi-shuttle automatedstorage and retrieval systems, IIE Trans 29(10):925-938, 1997.

[15] Lerher, T., Sraml, M., Potrc, I., Simulation analysis of mini-load multi-shuttle automated storage and retrieval systems, The Int. Journal of Adv. Manuf. Technology, 54 (1-4), 337-348, 2011.

[16] Oser, J., Garlock, P., Technology and throughput of double-deep multi-shuttle automated storage and retrieval system, Progress in material handling research, edited by R. J. Graves et. al., 409-423. Material Handling Institute, Charlotte, North Carolina, 1998.

[17] Oser, J., Ritonja, M., Expected cycle time in a class-based single and double-deep storage system, Progress in material handling research, edited by R. Meller et. al., 310-325. Material Handling Institute, Charlotte, North Carolina, 2004.

[18] Ritonja, M., Spielzeitberechnung Von Bedienstrategien Von Regalbediengäreten Mit MehrfachLastaufnahmemitteln (Traveltime calculation of operating strategies of storage and retrieval machines with multiple load handling devices), Ph.D. dissertation, Graz University of Technology, 2003.

[19] Sari, Z., Saygin, C., Ghouali, N., Travel-time models for flow-rack automated storage and retrieval systems, The Int. Journal of Adv. Manuf. Technology, 25(9-10), 979-987, 2005.

[20] De Koster, M. B. M., Le-Duc, T., Yu, Y., Optimal storage rack design for a 3-dimensional compact automated storage and retrieval systems, International Journal of Production Research, 46(6), 1495-1514, 2008.

[21] Yu, Y., De Koster, M. B. M., Designing an optimal turnover-based storage rack for a 3D compact $A S / R S$, International journal of production research, 47(6), 1551-1571, 2009.

[22] Yu, Y., De Koster, M. B. M., Optimal zone boundaries for two class-based compact 3D $A S / R S$, IIE Transactions, 41(3), 194-208, 2009.

[23] Lerher, T., Sraml, M., Potrc, I., Tollazzi, T., Travel time models for double-deep automated storage and retrieval systems, International Journal of Production Research, 48(11), 3151-3172, 2010.

[24] Xu, X., Shen, G., Yu, Y., Huang, W., Travel time analysis for the double-deep dual-shuttle AS/RS, International Journal of Production Research, 53 (3): 757-773, 2015.

[25] Gu, J., Goetschalckx, M., McGinnis, L. F., Research on warehouse design and performance evaluation: A comprehensive review, European Journal of Operational Research, 203(3), 539549,2010 . 
[26] Roodbergen, K. J., Vis, F. A., A survey of the literature on automated storage and retrieval systems. European Journal of Operational Research, 194, 343-362, 2009.

[27] Carlo, H. J., Vis, I. F. A., Sequencing dynamic storage systems with multiple lifts and shuttles. Int. J. Production Economics, (140), 844-853, 2012.

[28] Marchet, G., Melacini, M., Perotti, S., Tappia, E., Analytical model to estimate performances of autonomous vehicle storage and retrieval systems for product totes, International Journal of Production Research, 50(24), 7134-7148, 2012.

[29] Marchet, G., Melacini, M., Perotti, S., Tappia, E., Development of a framework for the design of autonomous vehicle storage and retrieval systems, International Journal of Production Research, 51(14), 4365-4387, 2013.

[30] Lerher, T., Ekren, B. Y., Dukic, G., Rosi, B., Travel time model for shuttle-based storage and retrieval systems, The Int. Journal of Adv. Manuf. Technology, 78(9-12): 1705-1725, 2015.

[31] Lerher, T., Ekren, B. Y., Sari, Z., Rosi, B., Simulation analysis of shuttle based storage and retrieval systems, International Journal of Simulation Modelling, 14(1), 48-59, 2015.

[32] Lerher, T., Travel time model for double-deep shuttle based storage and retrieval systems, International Journal of Production Researsch, Vol. 54, Issue 9, pp. 2519-2540, 2016.

[33] Lerher, T., Edl, M., Rosi, B., Energy efficiency model for the mini-load automated storage and retrieval systems, The Int. Journal of Adv. Manuf. Technology 68, (97-115), 2013.

[34] Lerher, T., Modern automation in warehousing by using the shuttle based technology, Automation Systems of the 21st Century: New Technologies, Applications and Impacts on the Environment \& Industrial Processes, edited by Doug Arent and Monica Freebush, 51-86. Nova Science Publishers, New York, 2013. 